\title{
Effects of breed on milk fatty acid profile in dairy ewes, with particular reference to cis-9, trans-11 conjugated linoleic acid
}

\author{
D. Mierlita ${ }^{1 \#}$, St. Daraban ${ }^{2}$ \& F. Lup ${ }^{1}$ \\ ${ }^{1}$ University of Oradea, Department of Animal Science, Oradea City, Romania \\ ${ }^{2}$ University of Agricultural Sciences and Veterinary Medicine Cluj-Napoca, Department of Animal Science, Cluj- \\ Napoca 400372, Romania
}

Copyright resides with the authors in terms of the Creative Commons Attribution 2.5 South African Licence.

See: http://creativecommons.org/licenses/by/2.5/za

Condition of use: The user may copy, distribute, transmit and adapt the work, but must recognise the authors and the South African Journal of Animal Science

\begin{abstract}
The objective of this study was to determine and compare the fatty acid profile of milk fat, with particular reference to cis-9, trans-11 conjugated linoleic acid (CLA), in two indigenous Romanian sheep breeds (Spanca and Turcana), irrespective of the effects of diet and season. The ewes ( $\mathrm{n}=25$ for each breed) received the same feed (total mixed rations) and were maintained under identical conditions. Four samples were collected from each individual ewe to determine fatty acids (FA), as methyl esters, using gas chromatography. The fatty acid groups, namely saturated (SFA), monounsaturated (MUFA) and polyunsaturated (PUFA) acids were examined together with individual acids. Differences have been obtained between the two local breeds for the majority of FA. Fat in the milk of Turcana ewes has a healthier fatty acid profile than that of Spanca breed which has a lower concentration of SFA (60.9 vs. 73.3\%) and higher concentrations of MUFA (31.0 vs. 21.0\%) and PUFA (8.06 vs. 5.61\%, respectively). Compared with the Spanca breed, fat in the milk of Turcana ewes had higher concentrations of trans-11 C18:1, C18:1 n9c, and cis-9 trans-11 CLA (2.67 vs. 1.01\%, respectively). $\Delta^{9}$-desaturase activity is breed specific; vaccenic acid (trans-11 C18:1) desaturation and its conversion into cis-9, trans-11 CLA were more intense in the Turcana breed ewes. In conclusion, breed has a strong effect on the FA composition of ewe milk fat, and on cis-9, trans-11 CLA, in particular. The results obtained, support the sustainable use of animal genetic resources to improve the milk fat quality of ewes.
\end{abstract}

Keywords: CLA, ewe's milk, fatty acid profiles, Spanca, Turcana

${ }^{\#}$ Corresponding author: dadi.mierlita@yahoo.com

\section{Introduction}

Manipulation of the fatty acid profile of milk fat with the help of dietary and physiological factors can benefit human health. N-3 polyunsaturated fatty acids (n-3 FA) and conjugated linoleic acid (CLA) have proved beneficial to human health, contributing to a better neurological function, prevention of cardiovascular diseases, prevention of certain forms of cancer, and to a stronger immune system (Pfeuffer \& Schrezenemeir, 2000; Sretenovic et al., 2009). The principal source of CLA in human diets is meat and milk from ruminant animals, since rumenic acid (RA), which is the main isomer of CLA, is produced from the ruminal biohydrogenation of linoleic acid (C18:2) and from endogenous conversion in the mammary gland and other tissues of vaccenic acid (VA, trans-11 C18:1).

Studies have shown that the fatty acid profile of ewe milk fat makes this milk particularly important to consumers, due to its positive effects on human health (Babayan \& Rosenau, 1991; Haenlein, 2002, Sretenovic et al., 2009). Nevertheless, there have been rather few studies carried out on the milk fatty acid profile of ewes; most studies being done on cow's milk. In addition, the majority of studies have focused primarily on the effect of diet on the fatty acid profile of milk fat (Addis et al., 2005; Mele et al., 2007; Gomez-Cortes et al., 2008; De La Fuente et al., 2009; Tyagi et al., 2010), the effect of physiological factors (e.g. breed, parity, stage of lactation) being less studied (Mihaylova et al., 2004; Tsiplakou et al., 2006; 
Gerchev \& Mihaylova, 2009). Similarly, little information is available on the fatty acid profile of local ovine breeds' milk (Signorelli et al., 2008; Talpur et al., 2009).

Milk obtained from indigenous Romanian sheep breeds is used primarily to make traditional cheeses such as "telemea" and "brânză de burduf", which are highly appreciated by consumers and have a high market value. The remarkable quality of traditional cheeses is linked to milk fat content and fatty acid profile, as the number of volatile compounds that result from their degradation during maturation give specific aromas and savour (McSweneey, 2004; Mele et al., 2007). No previous data on the FA composition of milk fat of Spanca and Turcana breeds were found in the literature.

In several studies carried out to determine the milk fatty acid profile in various ovine breeds, the ewes were maintained on different farms and their diet was pasture-based during the duration of the experiments. Such feeding practices do not ensure results that can be compared, at least between breeds, because recent studies have shown that differences in pasture management, in the botanical composition of pastures and in the vegetative stages of plants, can affect the fatty acid composition of ewe milk fat (Cabiddu et al., 2003).

The goal of our study was to determine and compare the fatty acid profile of milk fat in two indigenous Romanian sheep breeds (Spanca and Turcana), irrespective of the effects of diet and season.

\section{Materials and Methods}

The study was conducted at the Oradea University Experiment Station (Romania) on two groups of 25 ewes each, with group I consisting of Spanca breed ewes and group II of Turcana breed ewes. The ewes were selected from private flocks, and both groups were balanced in respect of parity, body weight, date of lambing and breeding conditions (Table 1).

Table 1 Main characteristics of the ewes used in the experiment

\begin{tabular}{|c|c|c|c|c|}
\hline & \multicolumn{2}{|c|}{ Spanca breed } & \multicolumn{2}{|c|}{ Turcana breed } \\
\hline & Mean \pm SD & $(\min -\max )$ & Mean \pm SD & $(\min -\max )$ \\
\hline Parity & $2.32 \pm 0.30$ & $(1-4)$ & $2.14 \pm 0.27$ & $(1-4)$ \\
\hline Body weight (kg) & $39.7 \pm 1.99$ & $(35.7-42.5)$ & $41.8 \pm 1.8$ & $(38.8-44.2)$ \\
\hline $\begin{array}{l}\text { Born lambs and } \\
\text { suckled }\end{array}$ & 1 & - & 1 & - \\
\hline Days in milk & $85 \pm 12$ & $(70-97)$ & $81 \pm 22$ & $(72-95)$ \\
\hline
\end{tabular}

SD - standard deviation.

The study was conducted after lamb weaning, between April and July. The animals were managed according to guidelines comparable to those laid down by the Animal Ethics Committee (2009). In order to eliminate the confounding influences of diet (changes in pasture composition during the grazing period), season and farm management on milk fatty acid profile, the two ewe groups were kept in an enclosed facility as a single flock, under standard feeding conditions that were not pasture-based. The ewes were fed a total mixed ration (TMR) diet consisting of hay, maize silage and concentrates (Table 2). The final diet forage/concentrate ratio was $60: 40$. This diet eliminated any influence of nutritional factors on the results of the experiment and it also met the nutritional needs recommended for lactating ewes (Cannas, 2002).

Milk samples were collected four times during lactation, on the same day for all ewes, following the regulations of the International Committee for Animal Recording (ICAR) on collecting milk samples for milk quality analysis and FA gas chromatographic analysis. The samples were collected once a month from April to July, to cover the lactation period of the two local breeds. Thus, four samples for analysis were obtained from each ewe ( $\mathrm{n}=100$ for each breed). Each sample was divided into two parts, one for chemical analysis and the other one for fatty acid determination.

Milk samples were kept in $100 \mathrm{~mL}$ containers and preserved with two tablets of Bronopol (BroadSpectrum Micro-tabs II, D\&F Control Systems Inc., USA). The samples were refrigerated at $4{ }^{\circ} \mathrm{C}$ (for $24 \mathrm{~h})$ before being analyzed for fat, $\mathrm{CP}(\mathrm{N} \times 6.38)$ and total solids. The analysis was performed using a near- 
infrared spectroscopy analyzer (NIRS Systems 5000, Foss Electric A/S, Hillerød, Denmark). Calibration was checked using the AOAC (1990) reference methods.

Milk fatty acid content was assayed as follows: the fat fraction was separated by centrifugation (15 min at $9000 \mathrm{rpm}$ and $4{ }^{\circ} \mathrm{C}$ ) and then stored at $-20{ }^{\circ} \mathrm{C}$. Milk FA samples were analyzed after extraction of milk fat samples and methylation (Palmquist \& Jenkins, 2003). Milk fat samples (60 mg) were dissolved in $1 \mathrm{~mL}$ of benzene, which was followed by esterification using $2 \mathrm{~mL}$ of $0.5 \mathrm{~N}$ sodium methoxide in methanol $\left(50{ }^{\circ} \mathrm{C}\right.$ for $\left.10 \mathrm{~min}\right)$ and $3 \mathrm{~mL}$ of $100 \mathrm{~mL} / \mathrm{L}$ methanolic $\mathrm{HCl}\left(80^{\circ} \mathrm{C}\right.$ for $\left.10 \mathrm{~min}\right)$. After addition of $1 \mathrm{~mL}$ of heptane and $7 \mathrm{~mL}$ of $60 \mathrm{~g} / \mathrm{L} \mathrm{K}_{2} \mathrm{CO}_{3}$ and centrifugation, the top solvent layers were transferred to a Pyrex glass tube, $1 \mathrm{~g}$ of $\mathrm{Na}_{2} \mathrm{SO}_{4}$ was added, and the samples were centrifuged $\left(6000 \mathrm{x} g\right.$ and $\left.4{ }^{\circ} \mathrm{C}\right)$. The clear layers containing the FA methyl esters were transferred to a tube and stored at $-20^{\circ} \mathrm{C}$ until analysis. Separation and quantification of methyl esters was carried out using a gas chromatograph (Hewlett Packard Co., model 5890) equipped with a flame ionization detector and capillary column (CP-Sil-88; $100 \mathrm{~m} \mathrm{x} 0.25 \mathrm{~mm}$ i.d. with $0.20 \mu \mathrm{m}$ of capillary thickness; Varian Inc., Palo Alto, CA, USA). The column parameters were as follows: initial column temperature was kept at $70{ }^{\circ} \mathrm{C}$ for $2 \mathrm{~min}$; increased $15{ }^{\circ} \mathrm{C} / \mathrm{min}$ to $160{ }^{\circ} \mathrm{C}$ (held at this temperature for $25 \mathrm{~min}$ ), then increased at $3{ }^{\circ} \mathrm{C} / \mathrm{min}$ to $225{ }^{\circ} \mathrm{C}$ (held at this temperature for $15 \mathrm{~min}$ ). Individual FA were identified by comparison of retention times with those of pure standards (Sigma-Aldrich Quimica, Madrid, Spain) and expressed as percentages of the total FA detected as FA methyl esters. Retention times of CLA and isomers of C18:1 FA were checked by co-elution of samples with commercial preparations (Matreya Inc., State College, PA, USA) of these FA.

Table 2 Ingredient ( $\%$ of DM) and composition of experimental diet

\begin{tabular}{|c|c|c|c|}
\hline \multirow{2}{*}{$\begin{array}{l}\text { Composition } \\
\text { Ingredients }(\% \text { of } \mathrm{DM}) \\
\end{array}$} & \multicolumn{2}{|r|}{ Content } & \\
\hline & & Chemical composition $^{1}$ & \\
\hline Lucerne hay & 18.5 & $\mathrm{CP}$ (Crude protein) (\% of DM) & 13.43 \\
\hline Grass hay & 16.5 & NDF (Neutral detergent fibre) (\% of DM) & 38.7 \\
\hline Maize silage & 25.0 & ADF (Acid detergent fibre) ( $\%$ of DM) & 23.6 \\
\hline Triticale & 15.0 & $\mathrm{PDIE}^{2}(\mathrm{~g} / \mathrm{kg} \mathrm{DM})$ & 83 \\
\hline Maize & 13.0 & $\mathrm{PDIN}^{2}(\mathrm{~g} / \mathrm{kg} \mathrm{DM})$ & 84 \\
\hline Soybean meal & 9.3 & $\mathrm{NE}_{\mathrm{L}}^{3}(\mathrm{MJ} / \mathrm{kg} \mathrm{DM})$ & 6.72 \\
\hline Limestone & 0.7 & & \\
\hline Minerals and vitamins & 1.0 & & \\
\hline Sodium bicarbonate & 1.0 & & \\
\hline Forage/concentrate ratio & $60: 40$ & & \\
\hline
\end{tabular}

DM - Dry matter.

${ }^{1}$ Calculated values (INRA, 1989).

${ }^{2}$ PDIN and PDIE - Digestible CP in the intestine from microbial protein synthesis when availability of fermentable $\mathrm{N}$ in the rumen is limited, and from microbial protein synthesis when availability of energy in the rumen is limited, respectively (INRA, 1989).

${ }^{3} \mathrm{NE}_{\mathrm{L}}$ - Net Energy for lactation.

Before analysis, the data on the fatty acid profile of milk fat was processed to calculate the content of the saturated fatty acids (SFA), monounsaturated fatty acids (MUFA) and polyunsaturated fatty acids (PUFA), and in the case of PUFA the n-6/n-3 ratio was calculated according to Ellis et al. (2006). The following parameters were also calculated: $\Delta^{9}$-desaturase ratios according to Kelsey et al. (2003) as product of $\Delta^{9}$-desaturase/(product of $\Delta^{9}$-desaturase + substrate of $\Delta^{9}$-desaturase); and the atherogenicity index according to Chilliard et al. (2003), thus (C12:0 + 4 x C14:0 + C16:0)/(MUFA + PUFA). 
The data obtained was statistically analyzed by an ANOVA using SAS (SAS Inst. Inc., Cary, NC, USA) for significant F-statistics. If the overall F-test was significant $(P<0.05)$, a Fisher's t-test was performed to discern differences between the breeds.

\section{Results and Discussion}

A number of studies (Haenlein, 2002; Addis et al., 2005; Tsiplakou et al., 2006; Signorelli et al., 2008) have demonstrated that breed effects milk yield and its components in ewes. The data in Table 3 confirm the fact that after lamb weaning, Turcana ewes yielded more milk $(687.8 v s .531 .3 \mathrm{~g} / \mathrm{day} ; P<0.05)$, and that the daily fat and protein yield were higher $(P<0.05)$ than that of Spanca ewes $(47.1 \mathrm{vs} .35 .6 \mathrm{~g} / \mathrm{day}$, and $35.3 v s .27 .1 \mathrm{~g} /$ day, respectively).

No previous data on the FA composition of milk fat of Spanca and Turcana breeds were found in the literature. In recent literature it is evident that only Signorelli et al. (2008) and Talpur et al. (2009) have studied the effect of breed on milk fatty acid profile in ewes. Most studies have focused on determining the effect of diet on the fatty acid profile of milk fat. Assessing the effect of breed on the fatty acid composition of milk fat was not considered a priority. This can be explained by the fact that each breed, and indigenous ones in particular, are of interest only in the geographical area where they are raised.

Table 3 Milk production parameters for the experimental ewe breeds

\begin{tabular}{|c|c|c|c|c|c|c|c|}
\hline & \multicolumn{3}{|c|}{ Spanca breed } & \multicolumn{3}{|c|}{ Turcana breed } & \multirow{2}{*}{$P$-value ${ }^{1}$} \\
\hline & Mean & $(\min -\max )$ & $\mathrm{SD}$ & Mean & $(\min -\max )$ & SD & \\
\hline $\begin{array}{l}\text { Daily milk yield } \\
\text { (g/day) }\end{array}$ & 531.3 & $(313-824)$ & 125.8 & 687.8 & $(278-1136)$ & 174.2 & $* *$ \\
\hline Fat $(\mathrm{g} / \mathrm{kg})$ & 66.2 & $(47-97)$ & 9.7 & 68.4 & $(49-118)$ & 17.3 & ns \\
\hline Protein $(\mathrm{g} / \mathrm{kg})$ & 50.8 & $(43-62)$ & 3.9 & 51.1 & $(41-65)$ & 8.6 & ns \\
\hline $\mathrm{TS}^{2}(\mathrm{~g} / \mathrm{kg})$ & 157.1 & $(116-192)$ & 24.3 & 161.3 & $(124-237)$ & 47.7 & ns \\
\hline Fat yield (g/day) & 35.6 & $(22-61)$ & 4.8 & 47.1 & $(20-84)$ & 6.6 & $* *$ \\
\hline Protein yield (g/day) & 27.1 & $(20-57)$ & 2.6 & 35.3 & $(23-61)$ & 4.2 & $* *$ \\
\hline
\end{tabular}

The findings on the milk fatty acid profile for the two breeds, and the calculated values for the fatty acid groups, the n-6/n-3 FA ratio, $\Delta^{9}$-desaturase ratios and atherogenicity index are shown in Table 4 . We have found differences in milk fat compositions both in the saturated FA group (73.3 and $60.9 \%$ of the total FA in Spanca ewes vs. Turcana ones; $P<0.01)$ and in the unsaturated FA group $(26.7$ and $39.1 \%$ in Spanca $v s$. Turcana; $P<0.01$ ). A smaller proportion of SFA in the milk fat of Turcana ewes seems to be beneficial to human health due to their negative role in atherosclerosis (Pfeuffer \& Schrezenmeir, 2000).

Similar findings to ours, on the FA groups in milk fat, have been reported in Altamurana and Gentile di Puglia (Italy) indigenous sheep breeds by Signorelli et al. (2008) in Karakachan breed (Bulgaria) by Mihaylova et al. (2004) and in Kooka and Kachi breeds (Pakistan) by Talpur et al. (2009). A greater proportion of SFA was found in the milk fat of the Lacaune breed by Bouattour (2007) and in that of the Sarda breed by Addis et al. (2005) and Cabiddu et al. (2006). All these coincide with the findings of Kay et al. (2005) in cow breeds, which show that selection for milk yield elevated the SFA proportion in the fatty acid profile of milk fat.

Within the SFA group, palmitic acid (C16:0) and myristic acid (C14:0) had the highest proportions in both breeds' milk fat, with values between 24.1 to $26.3 \%$ and 8.9 to $12.4 \%$, respectively, of the total FA. In the local breeds studied by us, milk fat stearic $(\mathrm{C} 18: 0)$ and butyric $(\mathrm{C} 4: 0)$ acids reached lower values (7.8 to $7.8 \%$ and 1.7 to $1.9 \%$, respectively, of total FA) than those reported by Mihaylova et al. (2004); Addis et al. 
(2005); Collomb et al. (2006); Signorelli et al. (2008) and Talpur et al. (2009) (10.6 to 14.7 and 3.3 to 4.4\%, respectively, in various sheep breeds). The differences can be partly explained by differences in fodder intake, by variations in the acetyl-CoA carboxylase activity and of other enzymes involved in de novo saturated fatty acid synthesis in the mammary gland (Bernard et al., 2005), but also by increased de novo PUFA lipogenesis in the mammary cells (Chilliard et al., 2003).

There have been recorded differences $(P<0.05)$ between Spanca and Turcana breeds for most SFA (Table 4), especially for those ones that have a higher proportion in the FA composition of milk: palmitic, myristic, capric, lauric, caprylic and caproic acids. All these saturated FA had a lower proportion in the milk fat obtained from the Turcana breed vs. the Spanca breed. The differences recorded between the two breeds, mainly those in C14:0 and C16:0, might influence significantly the characteristics of the cheeses obtained, as Engels et al., (1997) discovered that volatile organic compounds (VOCs), like methyl ketones and

Table 4 Effect of breed on milk fat fatty acid (FA) composition ( $\%$ of total FAME)

\begin{tabular}{|c|c|c|c|c|c|c|c|c|c|}
\hline \multirow{2}{*}{ Fatty acids } & \multicolumn{4}{|c|}{ Milk of Spanca breed } & \multicolumn{4}{|c|}{ Milk of Turcana breed } & \multirow{2}{*}{$\begin{array}{c}P- \\
\text { value }^{1}\end{array}$} \\
\hline & Mean & Min. & Max. & $\mathrm{SD}$ & Mean & Min. & Max. & $\mathrm{SD}$ & \\
\hline $\mathrm{C} 4: 0$ & 1.90 & 1.76 & 2.15 & 0.22 & 1.69 & 1.02 & 2.23 & 0.17 & ns \\
\hline C6:0 & 2.53 & 2.37 & 2.61 & 0.47 & 1.73 & 1.38 & 2.05 & 0.55 & $* *$ \\
\hline $\mathrm{C} 8: 0$ & 2.98 & 2.82 & 3.11 & 0.64 & 1.99 & 1.22 & 1.96 & 0.48 & $* *$ \\
\hline $\mathrm{C} 10: 0$ & 11.06 & 10.47 & 11.75 & 1.81 & 8.22 & 6.69 & 9.72 & 2.13 & $* *$ \\
\hline $\mathrm{C} 12: 0$ & 5.99 & 5.48 & 7.55 & 1.22 & 4.31 & 3.56 & 5.28 & 0.71 & $* *$ \\
\hline C14:0 & 12.40 & 11.07 & 12.82 & 1.41 & 8.89 & 7.72 & 10.06 & 0.97 & $* *$ \\
\hline C14:1 & 0.18 & 0.15 & 0.20 & 0.07 & 0.16 & 0.14 & 0.19 & 0.06 & ns \\
\hline C15:0 & 1.04 & 0.89 & 1.21 & 0.27 & 0.93 & 0.85 & 1.37 & 0.22 & ns \\
\hline C16:0 & 26.28 & 24.90 & 27.47 & 1.12 & 24.12 & 23.34 & 25.62 & 0.97 & $* *$ \\
\hline C16:1 & 0.67 & 0.55 & 0.75 & 0.08 & 0.74 & 0.68 & 0.86 & 0.15 & ns \\
\hline C17:0 & 0.59 & 0.53 & 0.69 & 0.09 & 0.58 & 0.53 & 0.65 & 0.07 & ns \\
\hline C17:1 & 0.13 & 0.11 & 0.15 & 0.07 & 0.17 & 0.16 & 0.19 & 0.06 & ns \\
\hline C18:0 & 7.83 & 7.56 & 8.22 & 0.91 & 7.78 & 6.96 & 8.10 & 1.45 & ns \\
\hline $\mathrm{C} 18: 1 \mathrm{n} 9 \mathrm{t}$ & 0.67 & 0.62 & 0.78 & 0.15 & 0.88 & 0.74 & 1.07 & 0.22 & ns \\
\hline Trans-11 C18:1 (TVA) & 3.60 & 3.55 & 3.71 & 0.64 & 5.75 & 4.47 & 8.55 & 1.42 & $* * *$ \\
\hline $\mathrm{C} 18: 1 \mathrm{n} 9 \mathrm{c}$ & 15.44 & 14.58 & 16.05 & 0.88 & 22.48 & 20.11 & 23.55 & 1.76 & $* * *$ \\
\hline Cis-11 C18:1 & 0.75 & 0.71 & 0.84 & 0.21 & 1.05 & 0.78 & 1.23 & 0.38 & ns \\
\hline $\mathrm{C} 18: 2 \mathrm{n}-6 \mathrm{t}$ & 0.32 & 0.28 & 0.40 & 0.09 & 0.49 & 0.45 & 0.73 & 0.14 & ns \\
\hline C18:2 n-6c & 3.38 & 2.96 & 4.21 & 0.87 & 3.85 & 3.12 & 4.35 & 0.97 & ns \\
\hline Cis-9, trans-11 CLA & 1.01 & 0.79 & 1.81 & 0.82 & 2.67 & 2.07 & 3.81 & 1.15 & $* * *$ \\
\hline C18:3 n-3 & 0.87 & 0.80 & 0.92 & 0.08 & 1.01 & 0.76 & 1.26 & 0.15 & ns \\
\hline C20:0 & 0.32 & 0.28 & 0.37 & 0.07 & 0.37 & 0.33 & 0.42 & 0.09 & ns \\
\hline $\mathrm{C} 22: 0$ & 0.14 & 0.12 & 0.17 & 0.05 & 0.18 & 0.13 & 0.04 & 0.07 & ns \\
\hline$n-6 / n-3$ & 4.36 & 3.87 & 4.91 & 1.17 & 4.39 & 3.86 & 4.80 & 0.28 & ns \\
\hline Saturated FA & 73.27 & 71.24 & 76.54 & 2.96 & 60.88 & 59.70 & 63.85 & 2.45 & $* * *$ \\
\hline Unsaturated FA & 26.65 & 24.35 & 30.73 & 2.66 & 39.07 & 36.87 & 43.29 & 2.86 & $* * *$ \\
\hline MUFA & 21.04 & 19.74 & 23.56 & 1.86 & 31.01 & 28.99 & 32.75 & 2.16 & $* * *$ \\
\hline PUFA & 5.61 & 4.31 & 6.56 & 1.48 & 8.06 & 5.37 & 10.21 & 2.02 & $* * *$ \\
\hline TVA/CLA & 3.58 & 2.79 & 4.83 & 0.66 & 2.15 & 1.35 & 3.24 & 0.78 & $* * *$ \\
\hline Atherogenicity index & 3.11 & 2.69 & 3.89 & 0.54 & 1.67 & 1.39 & 2.14 & 0.48 & $* * *$ \\
\hline \multicolumn{10}{|l|}{$\Delta^{9}$-desaturase ratios } \\
\hline $\mathrm{C} 16$ & 0.020 & 0.014 & 0.028 & 0.01 & 0.026 & 0.020 & 0.033 & 0.01 & $* *$ \\
\hline $\mathrm{C} 18$ & 0.684 & 0.537 & 0.765 & 0.15 & 0.709 & 0.578 & 0.787 & 0.14 & ns \\
\hline CLA & 0.219 & 0.203 & 0.231 & 0.05 & 0.317 & 0.263 & 0.314 & 0.06 & $* * *$ \\
\hline
\end{tabular}

$\mathrm{SD}=$ standard deviation.

FAME - Fatty acids methyl esters; CLA - conjugated linoleic acid; MUFA - monounsaturated fatty acids.

PUFA - polyunsaturated fatty acids.

$1 * * P<0.05 ; * * * P<0.01 ; \mathrm{ns}=$ non-significant at $P>0.05$. 
secondary alcohols in cheese, result from the lipolysis of myristic and palmitic acids. Significant differences in milk fat palmitic, myristic and capric acid proportions between various sheep breeds have also been reported by Bouattour (2007) (Mancheg vs. Lacaune); Signorelli et al. (2008) (Sarda vs. Altamurana vs. Gentile di Puglia) and Talpur et al. (2009) (Kachi vs. Kooka).

From the data presented in Table 4 it is clear that the sum of MUFA was higher $(P<0.01)$ in the milk of Turcana ewes than that of Spanca ewes (31.0 vs. 21.0\% of the total FA). The MUFA concentration in Turcana ewes' milk was comparable with that reported by Bouattour (2007) for Lacaune and Mancheg breeds, and higher than that mentioned in the scientific literature for other breeds (Mihaylova et al., 2004; Signorelli et al., 2008; Talpur et al., 2009).

The isomers of oleic acid $(\mathrm{C} 18: 1)$ in milk fat showed differences $(P<0.01)$ between the two breeds. Both vaccenic acid (trans-11 C18:1; TVA) and the C18:1 n9c isomer had higher proportions in the milk fat of Turcana ewes than in that of Spanca ones (59.7\% higher and $45.6 \%$ higher, respectively). The TVA recorded in the Spanca breed is comparable to that mentioned for other breeds in the scientific literature (Mihaylova et al., 2004; Bouattour et al., 2007), but the one obtained for the Turcana breed (5.8\% of the total FA) is much higher, being comparable to that obtained in Lacaune breed ewes by supplementing their diet with soybean oil (5.4 to $5.7 \%$ of the total FA) (Bouattour et al., 2007). The higher trans-11 C18:1 concentration in milk can be explained by decreased rumen biohydrogenation of PUFA. This idea is supported by a lower stearic acid proportion, which is the end product of biohydrogenation of TVA (Tsiplakou et al., 2006). Thus, the premise is created that elevating the concentration of CLA, as TVA in the mammary gland, via $\Delta^{9}$-desaturase, it is converted into rumenic acid (RA; cis-9, trans-11 C18:2), which is the most important isomer of CLA (Chilliard et al., 2003).

Differences $(P<0.01)$ were also recorded in milk polyunsaturated FA content, with a higher level in Turcana ewes' milk fat ( 8.1 vs. $5.6 \%$ of the total FA). PUFA values in milk fat are comparable to those mentioned in the literature, sometimes even lower (Mele et al., 2006; Bouattour, 2007; Signorelli et al., 2008). These differences are the result of diet, as in all these studies the ewes' diets were either pasture-based or supplemented with various fat sources. Pasture-based diets or fat sources added to ewes' diets elevate the PUFA proportion in milk fat (Addis et al., 2005; Valvo et al., 2006). Our experimental design eliminated the confounding effects of diet, as the ewes were not pasture-fed and were not given fat supplements. Even under these conditions the PUFA levels in Turcana ewes' milk fat were clearly higher than those mentioned in literature for other breeds (Sarda, Lacaune, Tsigay).

The mean proportions of linoleic acid (C18:2 n-6) did not differ between the two breeds and are comparable to data in literature (e.g. Valvo et al., 2006; Signorelli et al., 2008).

In this study particular attention was given to the n-3 FA and CLA content of milk fat, due to the beneficial effects of these FA on human health (Sretenovic et al., 2009). The values recorded for $\alpha$-linolenic acid (C18:3 n-3; ALA), which has the highest proportion in the n-3 FA group, do not differ between the two breeds $(P>0.05)$. This fatty acid is primarily of dietary origin, its concentration in milk depending on its quantity in the rumen (De La Fuente et al., 2009). However, Komprda et al. (2000) determined increased levels of $\alpha$-linolenic acid (1.0 to 1.3\%) in the milk fat of crossbreds of Czech Pied x Ayrshire x Red Holstein cattle.

The n-6/n-3 FA ratio did not differ for the two breeds (4.36 for Spanca breed and 4.39 for Turcana), but it was very close to the n-6/n-3 FA ratio recommended for the human diet (2:1 to 4:1; Sretenovic et al., 2009) and comparable to that quoted in literature for the fat in cow milk (4.7:1; Ellis et al., 2006) or in that of ewes (3.87 - 4.47 : 1; Bouattour, 2007).

Breed had a significant effect on the cis-9, trans-11 CLA concentration in milk fat, the highest values being recorded in Turcana ewes $(2.67 v s .1 .01 \%$ of the total FA; $P<0.01)$. A strong correlation was recored between TVA (trans-11 C18:1) and cis-9, trans-11 CLA in milk fat, on the one hand, and cis-9, trans-11 CLA and the $\Delta^{9}$ - desaturase ratios (Table 4), on the other hand; these correlations concur with the findings reported by Kay et al. (2005) in cow milk fat. The $\Delta^{9}$-desaturase enzyme acts at the level of the mammary gland and it introduces a double bond with a $\Delta^{9}$ specificity, and in this way it converts vaccenic acid (trans$11 \mathrm{C} 18: 1$; TVA) into a conjugated linoleic acid isomer, that is, rumenic acid (cis-9, trans-11 C18:2; RA). The higher level of cis-9, trans-11 CLA in the milk fat of Turcana ewes is due to an increased $\Delta^{9}$-desaturase activity, which is shown by a higher $\Delta^{9}$-desaturase ratio $(0.31 v s .0 .21 ; P<0.01)$, but also to a higher TVA supply in the rumen. Data reported by Cabiddu et al. (2006) for $\Delta^{9}$-desaturase activity (RA/TVA+RA) in 
Sarda ewes was lower than those obtained by us or those reported in previous studies by Talpur et al. (2009). In addition, the TVA/CLA ratio in milk (3.58 in Spanca and 2.15 in Turcana ewes) suggests that in Turcana ewes a higher amount of TVA was converted into RA through desaturation; vaccenic acid being the precursor of rumenic acid, which represents over $90 \%$ of the total CLA (Luna et al., 2005). This supports the hypothesis of a breed-specific regulation of $\Delta^{9}$-desaturase activity.

According to Jahreis et al. (1999), CLA levels are the highest during the grazing period of ruminants and also higher in sheep's milk than in the milk of other species. Even in the case of a diet that was not pasture-based, the cis-9, trans-11 CLA level in Turcana ewes' milk fat was higher than that mentioned in the literature (e.g. $1.61 \%$ in Sarda ewes; $0.83 \%$ for Kooka breed; 0.50 to $0.53 \%$ in Lacaune and Awassi ewes).

The cis-9, trans-11 CLA content in milk fat varied significantly in individual ewes, the variation being confirmed by high S.D. values.

Effects of breed on milk fat CLA content have been reported previously both in cows (White et al., 2001; Pesek et al., 2005) and in ewes (Mihaylova et al., 2004; Talpur et al., 2009), but were not confirmed by Tsiplakou et al. (2006), who studied milk CLA content in four sheep breeds that were maintained under identical feeding conditions.

Milk fat is usually considered to be proatherogenic, mainly because of the presence of a large amount of saturated fatty acids (mainly lauric, myristic and palmitic acids). The atherogenic index is a criterion for the level and interrelation of some fatty acids that may have atherogenic properties. In our study we determined that the atherogenic index had lower values $(P<0.01)$ in Turcana ewes' milk fat than in that of Spanca ewes (1.67 vs. 3.11). This may be related, for example, to the increased concentration of cis-9, trans$11 \mathrm{C} 18: 2$ CLA, which is now described as having antiatherogenic properties (Cieslak et al., 2010).

\section{Conclusions}

In this study significant differences in most FA between the two local breeds were evident. This demonstrates that breed markedly affects the FA profile in ewes' milk fat, with particular reference to cis-9, trans-11 C18:2, which is considered beneficial to human health. Turcana breed ewes' milk fat has a healthier fatty acid profile than that of Spanca breed ewes, characterized by a lower content in saturated FA (60.9 vs. $73.3 \% ; P<0.01)$ and a higher content in polyunsaturated FA (8.06 vs. 5.61\%; $P<0.01)$, and especially in cis9, trans-11 CLA (2.67 vs. 1.01\%; $P<0.01)$. These results support the sustainable use of animal genetic resources to improve ewe milk fat quality.

\section{Acknowledgements}

This work was supported by CNCSIS - UEFISCSU, project number PN II - IDEI 679/2008.

\section{References}

Animal Ethics Committee, 2008. Animal Ethics Committee of the ARC-Animal Production Institute, Irene, South Africa.

Addis, M., Cabiddu, A., Pinna, G., Decandia, M., Piredda, G., Pirisi, A. \& Molle, G., 2005. Milk and cheese fatty acid composition in sheep fed Mediterranean forages with reference to conjugated linoleic acid cis-9, trans-11. J. Dairy Sci. 88, 3443-3454.

AOAC, 1990. Official Methods of Analysis. 1, $15^{\text {th }}$ ed. Association of Official Analytical Chemists, Washington, D.C., USA.

Babayan, V.K. \& Rosenau, J.R., 1991. Medium chain trigyceride cheese. Food Technol. 45, 111-114.

Bernard, L., Rouel, J., Leroux, C., Ferlay, A., Faulconnier, Y., Legrand, P. \& Chilliard Y., 2005. Mammay lipid metabolism and milk fatty acids secretion in Alpine goats fed vegetable lipids. J. Dairy Sci. 88, 1478-1489.

Bouattour, M.A., Casals, R., Albanell, E., Such, X. \& Caja, G., 2007. Milk CLA and fatty acids profile in milk from Lacaune ewes fed whole safflower grains. The $5^{\text {th }}$ International Symposium on the Challenge to Sheep and Goats milk, I-P014, April 2007; Sardinia, Italy.

Cabiddu, A., Carta, G., Molle, G., Decandia, M., Addis, M., Piredda, G., Delogu, A., Pirisi, A., Lai, V., Cera, V., Taras, L., Lallai, C. \& Banni, S., 2003. Relationship between feeding regime and content of conjugated linoleic acid in sheep milk and cheese. Seminar "Sustainable Grazing, Nutritional Utilization and Quality of Sheep and Goat Products", 67, 171-175, Granada (Spain). 
Cabiddu, A., Addis, M., Pinna, G., Decandia, M., Sitzia, M., Piredda, G., Pirisi, A. \& Molle, G., 2006. Effect of corn and beet pulp based concentrates on sheep milk and cheese fatty acid composition when fed Mediterranean fresh forages with particular reference to conjugated linoleic acid cis-9, trans-11. Anim. Feed Sci. Technol. 131, 292-311.

Cannas, A., 2002. Feeding of lactating ewes. Dairy Sheep Feeding and Nutrition. Ed. Pulina, G., Avenue Media, Bologna, Italy. pp. 123-166.

Chilliard, Y., Ferlay, A., Rouel, J. \& Lambere, G., 2003. A review of nutritional and physiological factors affecting goat milk synthesis and lipolysis. J. Dairy Sci. 86, 1751-1770.

Cieslak, A., Kowalczyk, J., Czauderna, M., Potkanski, A. \& Szumacher-Strabel, M., 2010. Enhancing unsaturated fatty acids in ewe's milk by feeding rapeseed or linseed oil. Czech J. Anim. Sci. 55 (11), 496-504.

Collomb, M., Butikofer, U., Maurer, J. \& Sieber, R., 2006. Composition en acides gras du lait de brebis produit a diverses altitudes. Revue suisse Agriculture 38 (6), 335-339.

De La Fuente, L.F., Barbosa, E., Carriedo, J.A., Gonzalo, C., Arenas, R., Fresno, J.M. \& San Primitivo, F., 2009. Factors influencing variation of fatty acid content in ovine milk. J. Dairy Sci. 92, 3791-3799.

Ellis, K.A., Innocent, G., Grove-White, D., Cripps, P., McLean, G.W., Hovard, C.V. \& Mihm, M., 2006. Comparing the fatty acid composition of organic and conventional milk. J. Dairy Sci. 89, 1938-1950.

Engels, W., Dekker, R., De Jong, C., Neeter, R. \& Visser, S., 1997. A comparative study of volatile compounds in the water-soluble fraction of various types of ripened cheese. Int. Dairy J. 7, 255-267.

Gerchev, G. \& Mihaylova, G., 2009. Variation in fatty acid composition of milk from Tsigai sheep in the region of Central Balkan Mountains. Biotech. Anim. Husb. 25 (5-6), 945-952.

Gomez-Cortes, P., Frutos, P., Mantecon, A.R., Juarez, M., De La Fuente, M.A. \& Hervas, G., 2008. Addition of olive oil to dairy ewe diets: Effect on milk fatty acid profile and animal performance. J. Dairy Sci. 91, 3119-3127.

Haenlein, G.F.W., 2002. Nutritional value of sheep milk. Sheep Dairy News 19, 5-11.

INRA, 1989. Ruminant Nutrition. Recommended allowances and feed tables. Ed. Jarrige, R., John Libbrey \& INRA, London \& Paris. pp. 193-212.

Jahreis, G., Fritsche, J., Moeckel, P., Schoene, F., Muller, U. \& Steinhart, H., 1999. The potential anticarcinogenic conjugated linoleic acid, cis-9, trans-11 C18:2, in milk of different species: cow, goat, ewe, sow, mare, woman. Nutr. Res. 19, 1541-1549.

Kay, J.K., Weber, W.J., Moore, C.E., Bauman, D.E., Hansen, L.E., Hansen, L.B., Chester-Jones, H., Crooker, B.A. \& Baumgard, L.H., 2005. Effects of week of lactation and genetic selection for milk yield on milk fatty acid composition in Holstein cows. J. Dairy Sci. 88, 3886-3893.

Kelsey, J.A., Corl, B.A., Collier, R.A. \& Bauman, D.M., 2003. The effect of breed, parity, and stage of lactation on conjugated linoleic acid (CLA) in milk fat from dairy cows. J. Dairy Sci. 86, 2588-2597.

Komprda, T., Dvorak, R., Suchy, P., Fialova, M. \& Sustova, K., 2000. Effect of heat-treated rapeseed cakes in dairy cow diet on yield, composition and fatty acid pattern of milk. Czech J. Anim. Sci. 45, 325-332.

Luna, P., Fontecha, J., Juarez, M. \& De la Fuente, M.A., 2005. Conjugated linoleic acid in ewe milk fat. J. Dairy Res. 72, 415-424.

McSweneey, P.L.H., 2004. Biochemistry of cheese ripening. Int. J. Dairy Technol. 57, 127-144.

Mele, M., Buccioni, A., Petacchi, F., Serra, A., Banni, S., Antongivanni, M. \& Secchiari, P., 2006. Effect of forage/concentrate ratio and soybean oil supplementation on milk yield, and composition from Sarda ewes. Anim. Res. 55, 273-285.

Mele, M., Serra, A., Conte, G., Pollicardo, A., Del Viva, M. \& Secchiari, P., 2007. Whole extruded linseed in the diet of dairy ewes during early lactation: effect on the fatty acid composition of milk and cheese. Ital. J. Anim. Sci. 6 (suppl. 1), 560-562.

Mihaylova, G., Gerchev, G., Moeckel, P. \& Jahreis, G., 2004. Comparative study on fatty acid content in milk of Tsigay and Karakachan sheep. Bulg. J. Vet. Med. 7 (3), 181-187.

Palmquist, D.L. \& Jenkins, T.C., 2003. Challenges with fats and fatty acid methods. J. Anim. Sci. 81, 3250-3254.

Pesek, M., Spicka, E. \& Samkova, E., 2005. Comparison of fatty acid composition in milk fat of Czech Pied cattle and Holstein cattle. Czech J. Anim. Sci. 50 (3), 122-128. 
Pfeuffer, M. \& Schrezenemeir, J., 2000. Bioactive substances in milk with properties decreasing risk of cardiovascular disease. Br. J. Nutr. 84, 155-159.

Signorelli, F., Contarini, G., Annicchiarico, G., Napolitano, F., Orru, L. \& Catillo, G., 2008. Breed differences in sheep milk fatty acid profiles: Opportunities for sustainable use of animal genetic resources. Small Rumin. Res. 78, 24-31.

Sretenovic, L.J., Pantelic, V. \& Novakovic, Z., 2009. Importance of utilization of omega-3 fatty acids in human and animal nutrition. Biotech. Anim. Husb. 25 (5-6), 439-449.

Talpur, F.N., Bhanger, M.L. \& Memon, N.N., 2009. Milk fatty acid composition of indigenous goat and ewe breeds from Sindh, Pakistan. J. Food Comp. Anal. 22 (1), 59-64.

Tsiplakou, E., Mountzouris, K.C. \& Zervas, G., 2006. The effect of breed, stage of lactation and parity on sheep milk fat CLA content under the same feeding practices. Livest. Sci. 105, 162-167.

Tyagi, A., Kaur, H., Kewalramani, N. \& Singhal, K.K., 2010. Effect of monensin supplementation on conjugated linoleic content in the milk of cow and buffaloes. Indian J. Anim. Sci. 80 (1), 49-52.

Valvo, M.A., Bella, M., Scerra, M. \& Biondi, L., 2006. Effects of ewe feeding system (grass $v s$ concentrate) on milk fatty acid composition. Options Mediterraneennes, Series A 74, 227-231.

White, S.L., Bertrand, J.A., Wade, M.R., Washburn, S.P., Green, J.T. \& Jenkins Jr., T.C., 2001. Comparison of fatty acid content of milk from Jersey and Holstein cows consuming pasture or total mixed ration. J. Dairy Sci. 84, 2295-2301. 